\section{DANDELION}

postgraduate arts journal \& research network

VOLUME 5 NUMBER I SUMMER 2014
DANIEL O'DonNell-SMith is a poet and musician. He is one half of VHS-pop adventurers and electronic mistake-makers Moscow Youth Cult. His chap book of poems, $<\mathrm{c}>$ Odes, was published by Leafe Press. Daniel is currently undertaking a practice-led PhD at Birkbeck College, which explores notions of code, voice and the occult.

Poetry

\title{
Author Statement
}

\author{
Daniel O'Donnell-Smith
}

Rhetoric is a Language Trick, Poetry is a Language Trap. The rhetorician uses language to attack, the poet attacks language - partly to usurp the hegemony of the alphabet I suppose (a power that NK Hayles grants to coding languages) and because we may feel that that's what poets have always done. To break apart language and syntax is analogous to breaking with tradition. I wonder if the [un]natural development of tradition can keep up with our enthusiasm for iconoclasm. The Last Poem will be the statue of a saint with its head lopped off. That is to say, a bit-crushed echo or the deformed daughter of a voice. Maybe there is no tradition, only precursors to something better, or else, as Eliot would have it, to break with tradition is in fact to extend it.

Sometimes I think that my poems are an outpouring of my cultural conscience, other times they are precisely because I lack one. Once I took a train to Stoke-on-Trent to get an old synth fixed. When I arrived I was despondent. I thought: 'this is where a city came to die'. It's strange how a neglected infrastructure can make one feel so helpless - it's like having your home stolen from you, but incrementally and over a long period of time. Nowadays we collect language and disseminate it online: content aggregators like BuzzFeed syndicate other people's work and proudly pass it off as their own. Perhaps there is a secret BuzzFeed City somewhere in New York State made entirely from stolen bits of Stoke-on-Trent.

The first creature I can remember killing was a bumble bee: I was about four years old and I squashed it with a piece of drift wood. These days I have lavender in my garden. A place for bees to buzz and feed, and a hive for the weaker conscience. 
polis state

when accounts are compromised

all the characters in the world mean nothing

A city is

an acte de culte a city is

where towns go to die

I heard fathers on why a city is

why spiders eat their parent or

their lover and why a city is

why red swallows holiday

in England is

/the necessity of egrets

darting about to catch insects is

between redder egrets [\&amp] original sash windows is

why fake orgasms are like fake poems

else Dickens liked 'winders'

masking tape

cloudy

your voice is there too 
show no blood

in tra trans mutabil ity

[states of change within a state of change

we had no interest in forming a party

perishable memory

you are tired from

song veins of leaves

autumn blood

menstrual lute and liar

when you get sick part of your book falls away

some erotic thought

green mind

an imagined family 
a wake within a wake

something Like a flick

Like a peel

something Like distortion

Like a VST

some thing threadd [\&amp] reflectiue

a thing for bokes

something Like a church

a brutal thing

Like forgetting his fingers

a burning plate with night in pursuit 
where's a narthria? [Soar Valley Massacre, 1987]

"What in the hell was that?*

"Sounded like it came from the back of the Great Central Way, near the old BMX track.**

“Oh shit, it's the General. OK - let's split up. You... hey wait, where's An_***? Guys, where's $\mathrm{An}_{-} * * * *$ ?

\section{$*$ explosion}

**[variant readings have: "caravan park" [\&amp] "hole in the head"

***[electronic harps + grey craters + verdant hills

****[each individual animal in soft craters for fifty years 